\title{
Whole genomic analysis of two influenza H3N2 virus strains isolated from Qinghai, China
}

\section{Huaxiang Rao}

Changzhi Medical College

\section{Hong Li}

Qinghai Center for Disease Control and Prevention

Nannan Lu

Qinghai Center for Disease Control and Prevention

\section{Youju Lei}

Qinghai Center for Disease Control and Prevention

\section{Shengcang Zhao}

Qinghai Center for Disease Control and Prevention Juan Yu ( $\square$ yujuan2006008@163.com )

\section{Research article}

Keywords: influenza virus, subtype H3N2, genome, sequence feature analysis

Posted Date: November 2nd, 2019

DOI: https://doi.org/10.21203/rs.2.16263/v2

License: (c) (1) This work is licensed under a Creative Commons Attribution 4.0 International License.

Read Full License 
The authors have withdrawn this preprint from Research Square 